POLSKA AKADEMIA NAUK-ZAKŁAD BADANIA SSAKÓW

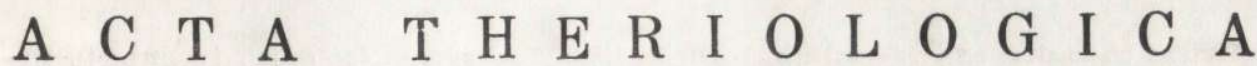

VOL. IX; 11: 149-164.

Władysław K U N I C K I - G O L D F I N G E R \& Władysława K U N I K A - G O L D F I N E R

\section{Seasonal Variations of Some Haematological Values in Small Mammals Living in Natural Environment}

\section{Sezonowe zmiany niektórych wskaźników hematologicznych u małych ssaków, żyjących w naturalnym środowisku}

\author{
[With 7 Figs, and 1 Table]
}

I. Introduction

II. Experimental

1. Materials and methods

2. Results

(150

a) Haemoglobin 150

b) Erythrocytes count . . . . . . . . . . . . . . 151

c) Mean corpuscular haemoglobin . . . . . . . . . . . . 151

d) Effect of age and sex . . . . . . . . . 151

e) Effect of parasitic infestation, of body weigth and length . . . 152

f) Effect of season of the year . . . . . . . . . . . . 154

g) Leucocytes count . . . . . . . . . . . . . . 155

3. Discussion . . . . . . . . . . . . . . . . . 156

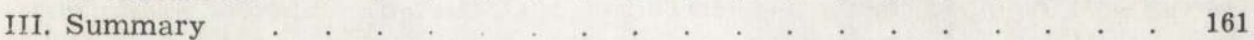

References . . . . . . . . . . . . . . . . . . 161

Streszczenie . . . . . . . . . . . 164

\section{INTRODUCTION}

Few haematological data on Sorex araneus L in na e us, 1758 and Clethrionomys glareolus ( $\mathrm{S} \mathrm{chreber,1780)}$ have been reported ( $\mathrm{K}$ le in e n ber g, 1952; K or ž ujev \& Koreckaja, 1962), but the counts were not complete and done on few animals. Only few reports on seasonal changes in blood of these or similar mammals have been met with (D a w s o n, 1956; N e ws o n, 1962; S e a l a n d e r, 1962).

The erythropoietic system is unfluenced by metabolic activity to a high degree. It may be then assumed that due to variable external conditions and internal stimuli, operating during different seasons of a year, the particular haematological 
indices should change accordingly during the year cycle. Not much is, unfortunately, known about such changes in wild animals living in their natural environment. The researches of $\mathrm{Dudzinski}$ et al. (1962) on the rabbit, Oryctolagus cuniculus I. in nae us, 1758 , kept in semi-natural conditions, and of L u cenko (1941) and G or odeckij (1962) on reindeer, should be mentioned in this connection. Similar observations on cattle ( $\mathrm{Smith} \& \mathrm{Kilbourne,} \mathrm{1893,} \mathrm{acc.} \mathrm{to} \mathrm{Riddle} \mathrm{\&} \mathrm{Bra} \mathrm{u-}$ $\mathrm{cher}, 1934$ ) and on sheep (Bulatova, 1962) are pertinent to discussed matter, if the effects of human activity, changing animals' diet, their habitat and even climate they live in, may be neglected.

In the present research an attempt has been made to study some haematologica] values for small wild rodents Clethrionomys glareolus ( $\mathrm{S} \mathrm{ch} \mathrm{re} \mathrm{be} \mathrm{r,} \mathrm{1780)} \mathrm{and} \mathrm{an}$ insectivorous Sorex araneus Lin na e us, 1758, living in their natural environment, relatively free of man's interference, in the forests of the National Park at Bialowieża.

\section{EXPERIMENTAL}

\section{Material and Methods}

The method of catching the animals and the characteristic of the biotope, they had lived in, have been given in the papers of Dehnel (1949) and Bor ows k i \& Dehne 1 (1952). The animals, being caught at early morning hours, were taken without delay to a nearby laboratory and then bled by snipping the end of the tail. In some cases, blood from $S$. araneus was obtained directly from the heart. When perallel samples were taken from the tail, no significant differences could be noticed between samples obtained in different ways. Acid haematin method and Sahli haemoglobinometer were used for haemoglobin $(\mathrm{Hb})$ determination. Enumeration of erythrocytes $(R B C)$ and leucocytes $(W B C)$ was done in Thoma haematocytometer, using Hayem's solution for $R B C$ and the diluting fluid (2 p.c. acetic acid + gentian violet) for $W B C$. The sex and the age of the animals were then determined, the animals were killed and passed to other subdivisions of the laboratory for examinations in the anatomical, histological, microbiological and parasitological respects.

For haemoglobin determinations 51 specimens of C. glareolus and 27 of S. araneus were used; for blood counts - 49 specimens of C. glareolus and 25 of $S$, araneus.

\section{Results}

Results of determinations are given in Table 1.

\section{a) Haemoglobin}

Comparative data on the haemoglobin concentration in blood of wild animals are scarse (W introbe, 1933; 1952). It is generally accepted that haemoglobin concentration is in all mammals constant. It seems yet, that domesticated animals' blood is slightly poorer in haemoglobin than in wild animals. The values obtained for $C$. glareolus and $S$. araneus are almost identical and are in accord with this impression (Fig. 1, Table 1). 


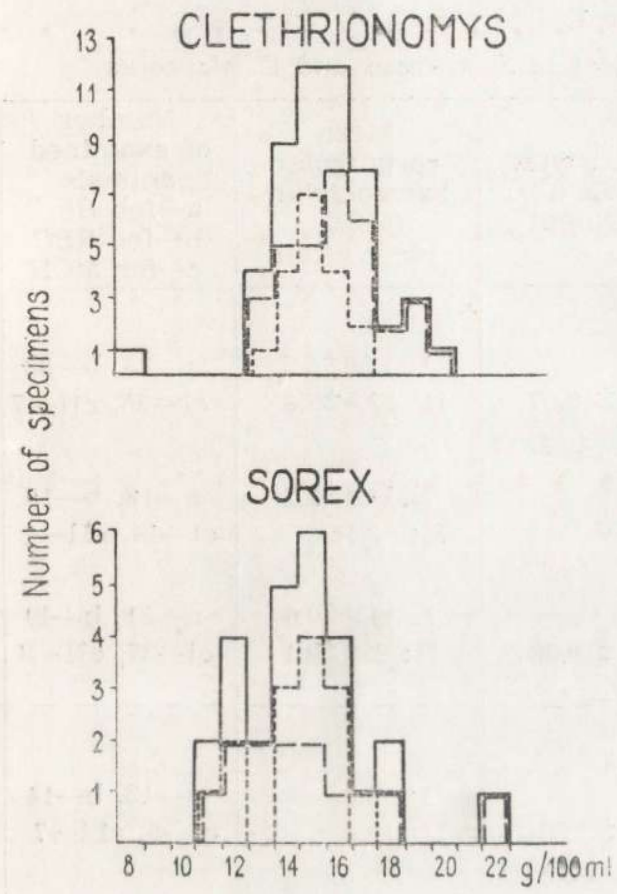

b) Erythrocytes count

The number of erythrocytes is variable in different animals. It is generally higher in small mammals; this tendency is deformed by some ecological factors, especially by the partial pressure of oxygen, being lower at higher altitudes. $R B C$ in $C$. glareolus is similar to that of the rat or of the ferret. In $S$. araneus, on the other hand, the values of $R B C$ are exceedingly high and variable (Table 1, Fig. 2).

Fig. 1. Distribution of haemoglobin levels in S. araneus and C. glareolus

c) The mean corpuscular haemoglobin $(\mathrm{MCH})$

Very little information is available with respect to this value in different mammals. This value may be yet related to efficiency of oxygen transport. $M C H$ is normal in C. glareolus and extremely low in S. araneus (Table 1, Fig. 3). This matter will be discussed in "Discussion".

The $M C H$ values for species could be further subdivided into two quite distinct groups (see Table 1, Fig. 3). This phenomenon, more marked in $S$. araneus, is yet quite apparent in C. glareolus, too. This heterogeneity of examined populations is due to the seasonal changes and will be discussed later.

\section{d) The effect of age and sex}

No statistically significant differences in $H b, R B C$, and $M C H$ values for different age groups were found. These values were, for a given season, similar for young adults and for the old ones, borne during the previous year.

The average values for both sexes were fairly close, when compared with the relatively broad range of normal values. Analysis of Fig. 1, 2 
Table 1.

Mean values of haematological indices in S. araneus and C. glareolus

\begin{tabular}{|c|c|c|c|c|}
\hline Animal & $\begin{array}{l}\text { Haemoglobin } \\
(\mathrm{Hb}) \\
\mathrm{g} / 100 \mathrm{ml}\end{array}$ & $\begin{array}{l}\text { Erythrocytes } \\
(R B C) \\
10^{6} / 1 \mathrm{~mm}^{3}\end{array}$ & $\begin{array}{c}\text { Mean } \\
\text { corpuscular } \\
\text { haemoglobin } \\
(M C H) \\
10^{-12} \mathrm{~g} / \text { cell }\end{array}$ & $\begin{array}{c}\text { Number } \\
\text { of examined } \\
\text { animals } \\
\text { a-for } H b \\
\text { b-for } R B C \\
\text { c-for } M C H\end{array}$ \\
\hline C. glareolus & & & & \\
\hline $\begin{array}{l}\text { males, mean } \\
\text { min. \& max. }\end{array}$ & $\begin{array}{l}16.2 \pm 0.7 \\
13.0-20.0\end{array}$ & $\begin{array}{r}10.02 \pm 0.57 \\
6.44-12.23\end{array}$ & $\begin{array}{r}\text { I: } 15.0 \pm 0.5 \\
\text { II: } 22.5 \pm 2.8\end{array}$ & $\begin{array}{l}a-33, b-33 \\
c I-25, c I I-7\end{array}$ \\
\hline $\begin{array}{l}\text { females, mean } \\
\min . \& \max .\end{array}$ & $\begin{array}{l}15.4 \pm 0.6 \\
13.8-17.6\end{array}$ & $\begin{array}{l}9.53 \pm 0.77 \\
6.50-13.22\end{array}$ & $\begin{array}{l}\text { I: } 14.8 \pm 1.2 \\
\text { II: } 2.15\end{array}$ & $\begin{array}{r}a-18, b-16 \\
c I-14, \text { cII-1 }\end{array}$ \\
\hline $\begin{array}{l}\sigma+q, \text { mean } \\
\text { min. \& max. }\end{array}$ & $\begin{array}{l}15.8 \pm 0.6 \\
13.0-20.0\end{array}$ & $\begin{array}{l}9.77 \pm 0.66 \\
6.44-13.22\end{array}$ & $\begin{array}{l}\text { I: } 14.9 \pm 0.6 \\
\text { II: } 223 \pm 2.1\end{array}$ & $\begin{array}{c}a-51, b-49 \\
c I-37, \text { cII }-8\end{array}$ \\
\hline Sorex araneus & & & & \\
\hline $\begin{array}{l}\text { males, mean } \\
\text { min. \& max. }\end{array}$ & $\begin{array}{l}15.1 \pm 1.76 \\
11.6-22.0\end{array}$ & $\begin{array}{c}12.17 \pm 1.98 \\
8.24-20.68\end{array}$ & $\begin{array}{l}\text { I: } 8.85 \\
\text { II: } 16.4\end{array}$ & $\begin{array}{l}a-13, b-14 \\
c I-5, \text { cI } I-7\end{array}$ \\
\hline females, mean & $14.8 \pm 1.28$ & $15.62 \pm 3.48$ & $\begin{array}{l}\text { I: } 9.3 \\
\text { II: } 17.3\end{array}$ & $\begin{array}{l}a-14, b--14 \\
c I-8, \text { cII-2 }\end{array}$ \\
\hline $\begin{array}{l}\sigma+q, \text { mean } \\
\text { min. \& max. }\end{array}$ & $\begin{array}{l}15.0 \pm 0.95 \\
11.0-22.0\end{array}$ & $\begin{array}{c}13.69 \pm 1.81 \\
7.23-25.10\end{array}$ & $\begin{array}{r}\text { I: } 9.1 \pm 0.7 \\
\text { II: } 16.6 \pm 1.1\end{array}$ & $\begin{aligned} a-27, & b-25 \\
c I-13, & c I I-9\end{aligned}$ \\
\hline
\end{tabular}

and 3 may, at the first sight, suggest the existence of slightly marked sexual dimorphism. This apparent dimorphism is yet caused by uneven distribution of examined specimens of both sexes during different seasons of the year. The analysis of the trend of examined values with season in both sexes separately, shows that differences between sexes for a given season are insignificant.

e) Effect of parasitic infestation, of body weight and lenght

The infestation by intestinal parasites was mild. The number of worms found in intestinal tract varied from 0 to over hundred specimens (Cesto$d a$ and Nematoda) per an animal. No correlation between kind or number of parasitic worms and haematological indices could be established.

There was no correlation between the values of haematological indices and the weight, the lenght of the animal's body or linear dimensions of liver, kidneys and spleen. 
Fig. 2. Distribution of erythrocytes counts in $S$. araneus and $C$. glareolus.

Fig. 3. Distribution of mean corpuscular haemoglobin concentrations in $S$. araneus and $C$. glareolus.
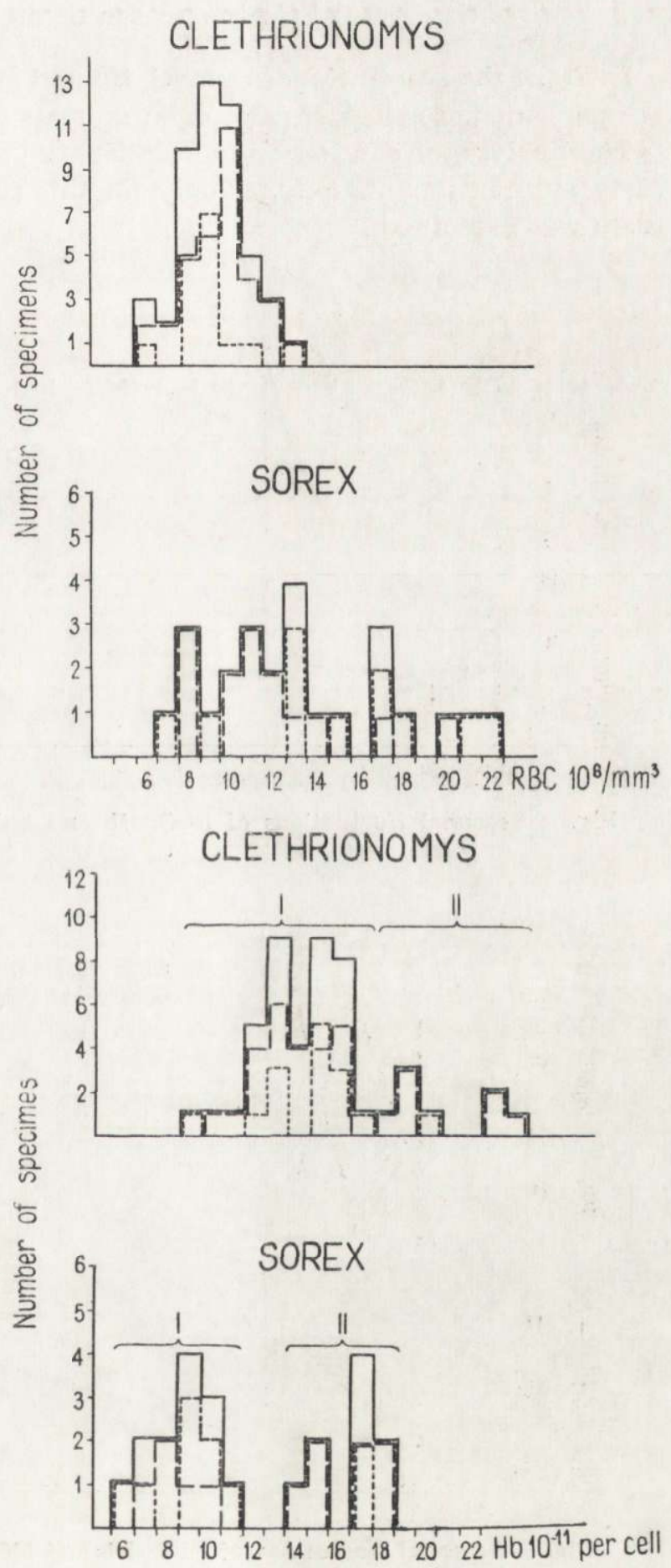


\section{f) Effect of season of the year}

In Fig. 4 the season trends of $R B C, H b$ and $M C H$ values for $C$. glareolus are presented. Analogical data for $S$. araneus are shown in Fig. 5.

The analysis of data on $S$. araneus has to be restricted to summer and early autumn months only, as only for this period sufficient number of cases was examined.

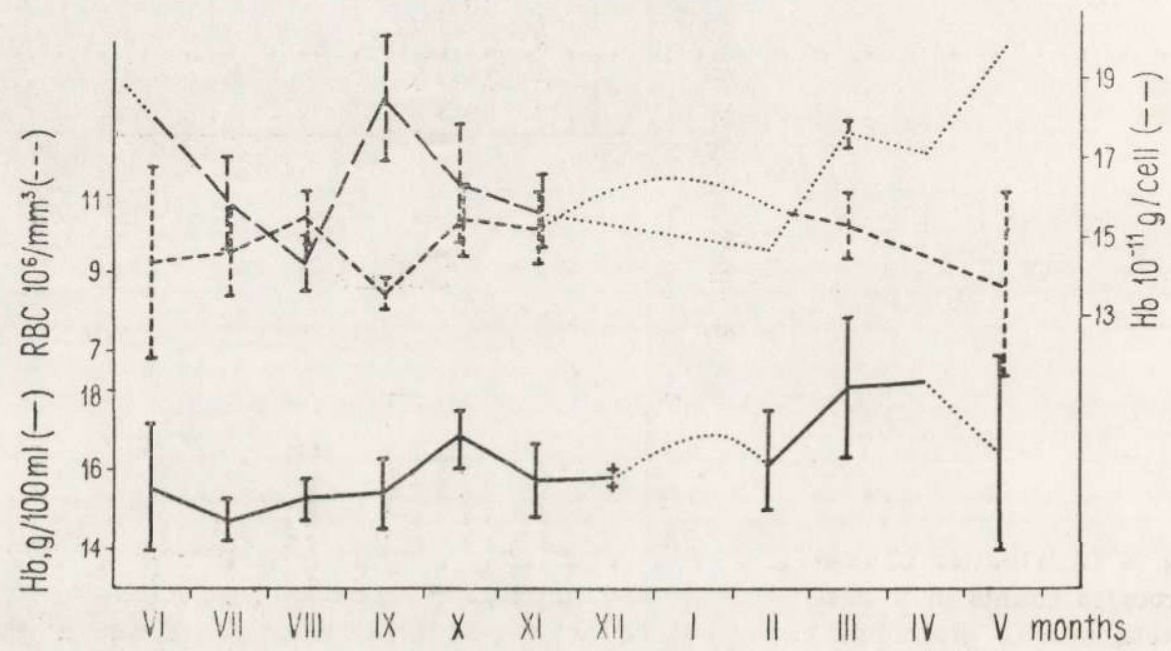

Fig. 4. Seasonal fluctuations of $R B C, H b$ and $M C H$ values in $C$. glareolus.

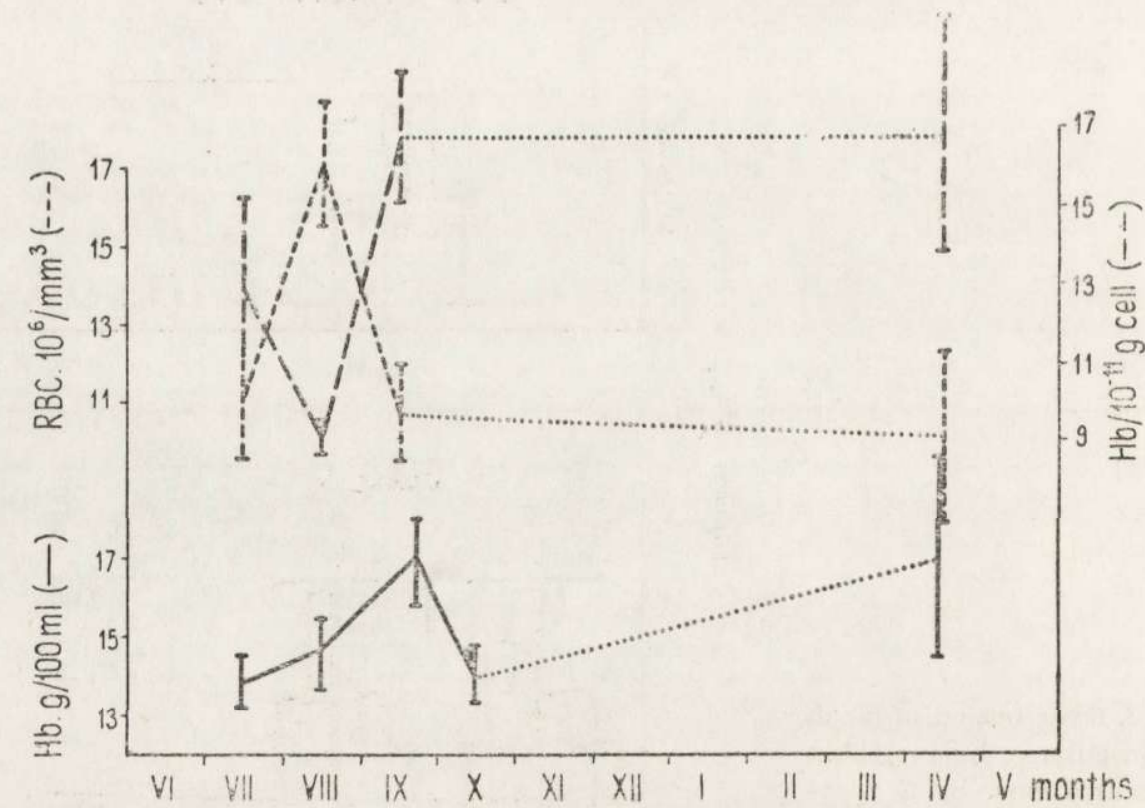

Fig. 5. Seasonal fluctuation of $R B C, H b$ and $M C H$ values in $S$. araneus. 
The $\mathrm{Hb}$ concentration was low at the beginning of the summer and rose sharply till the end of August, to drop again to the lowest level during September and October. Seasonal fluctations in $R B C$ counts were more pronounced, the peak coinciding with the end of the summer. Later, $R B C$ value diminished and this decrease seems to persist till the spring.

In C. glareolus the seasonal fluctuations were less striking than in $S$. araneus. On the other hand, the much greater number of specimens examined enabled to cover almost the whole year cycle. There were two distinct peaks in haemoglobin concentration, at spring and autumn. Correspondingly, the minimal $H b$ values were observed in late summer. The autumn peak of haemoglobin concentration developed in C. glareolus a month later than in $S$. araneus.

The fluctuations in erythrocytes counts had a different trend from the one observed in haemoglobin concentration. There were also two peaks, but more pronounced and displaced. The first peak in $R B C$ count was in

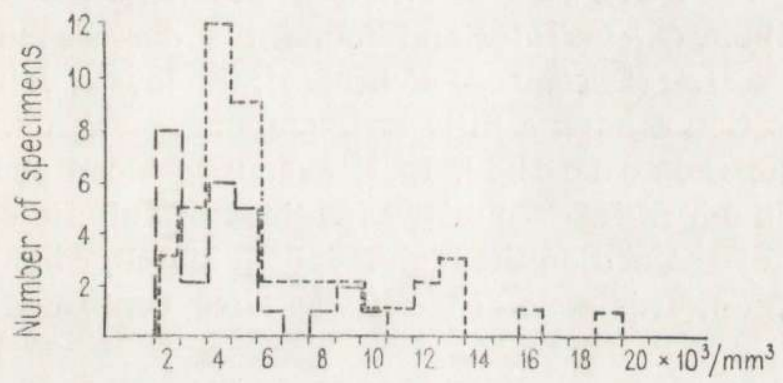

Fig. 6. Distribution of leucocytes counts in S. araneus and C. glareolus

late summer (August), the second one in late autumn (October-November). In $C$. glareolus seems to exist the third peak in $R B C$ count during the spring (March), but too small number of specimens examined during this season made the exact location of it difficult. The lowest values of $R B C$ counts were found in early autumn (September) and in late spring (May-June).

The trend in mean corpuscular haemoglobin concentration (MCH) was reversed in relation to the trend in $R B C$ count. The level of haemoglobin concentration had relatively small effect on the $M C H$ changes.

\section{g) Leucocytes count}

No relationship between leucocytes count and environmental or endogenous factors could be established (Table 1, Fig. 6). The observed values varied in ranges, which had been found by other workers, in small mammals. 


\section{Discussion}

Blood counts in S. araneus and C. glareolus and related species have been reported previously ( $\mathrm{K} \mathrm{n}$ oll, 1932, K l e i n e $\mathrm{n}$ b e r g, 1952; K orž u j e v \& K or e c k a ja, 1962) but they were done on only few animals, whose age, sex and conditions of life were not stated.

Previous informations on the effect of changes in environment on blood picture are scarse. Some informations, concerning domesticated animals, cattle ( $\mathrm{Smith} \& \mathrm{Kilburne,1893;} \mathrm{M} \mathrm{anres} \mathrm{a} \mathrm{et} \mathrm{al.} \mathrm{1934,}$ 1939; acc. to $\mathrm{Schalm}, 1961)$, sheep ( $\mathrm{B} u \mathrm{lat}$ a $\mathrm{va}, 1962)$, guinea pigs (B e nder \& de Witt acc. to Riddle \& Bra uch er, 1934) suggest that $R B C$ count diminished in winter. Pintor \& Grasini (1957) found seasonal changes in the rate of maturation of erythrocytes in rabbits.

Wild animals, living in their natural environment, were studied only exceptionally. Dudziński et al. (1962) studied seasonal changes in blood of the rabbit, $O$. cuniculus and found the decrease in $R B C$ count during the dry season (December-February); the lowest value of haemoglobin concentration coming a little later (January-February). L u c e nk o (1941 acc. to Gorod e cki j, 1962) examined blood picture in reindeer. The minimum in $R B C$ count was noticed in July; it was increased till October and remained on the high level till March, when spring-summer decline begun. This general trend was later confirmed by $\mathrm{G}$ or od e c ki j (1962).

Of special interest for the problem discussed here are publications by D a w s on (1956), N e w s on (1963) and S e a l a nd e r (1962). The research of $\mathrm{New}$ s o n, being conducted on C. glareolus in the field conditions, is especially valuable. She has found the highest values for haemoglobin concentration in winter, the lowest - in summer and autumn. Haematocrit values, like the weight of spleen, reached the highest level during summer and early autumn. N ews on (1963) excluded breeding, age, weather, ectoparasites, as chief factors affecting the examined indices. S e a l a n d e r (1962) has studied haemoglobin concentration, haematocrit values and erythrocyte diameters in three species of Peromyscus. The study has been concerned with caged animals, kept in natural weather conditions, but maintained on an ad libitum laboratory diet. Some measurements have been made also on free-living animals. S e a l a n d e r observed the highest levels of haemoglobin concentration and haematocrit values, simultaneously, in winter. Fairly good correlation between these indices and microhabitat temperature has been established.

In present research the changes in blood picture of wild animals have been studied throughout the whole year cycle. These changes are due to 
status of an individual animal. The status may be influenced by many variables, such as sex, age, diet, climatic factors and others.

It seems that circadian behaviour and connected with it changes in blood during a day cycle ( $\mathrm{H}$ a l be r g, 1960; M a $\mathrm{nres}$ a et al., 1934; 1939 ; acc. to $\mathrm{S} \mathrm{ch} \mathrm{a} \mathrm{l} \mathrm{m,} \mathrm{1961)} \mathrm{may} \mathrm{be} \mathrm{disregarded.} \mathrm{All} \mathrm{the} \mathrm{animals} \mathrm{ex-}$ amined were caught at the same time of a day, and the differencies caused by small deviations in the time of catching may be supposed to be unimportant.

No significant effect of sex on haematological indices has been observed, confirming thus Wintrobe's (1952) opinion. K a la bukhov's (1933) observations on sexual dimorphism in blood picture in Citellus pygmaeus $\mathrm{Pa} 1 \mathrm{las}, 1778$ seem to be founded on too small number of examined specimens and neglecting the eventual influences of seasonal and dietetary factors.

There was no dependance of blood picture on the age of examined animals. It is well known that in adult animals the age has no effect on haemoglobin concentration or $R B C$ count (D r o b k in \& F i t z- H u g h, 1934; Enzman, 1934; Dudziński et al., 1962; Ka la bukhov \& R o dinov, 1934). Juveniles among examined here animals were not numerous, the indices found for them followed general pattern of the population mean.

It is still one point to be elucidated. In very excitable animals the circulation, and consequently $R B C$ count and haemoglobin concentration, can be strongly influenced even by trifling occurences ( $\mathrm{H}$ a n s e $\mathrm{n}, 1950$; $\mathrm{S} \mathrm{ch} \mathrm{a} \mathrm{l} \mathrm{m,} \mathrm{1961).} \mathrm{The} \mathrm{stress} \mathrm{and} \mathrm{excitement} \mathrm{caused} \mathrm{in} \mathrm{animals} \mathrm{by} \mathrm{handl-}$ ing them during collecting of blood could play some role in this respect. The procedure of handling animals was, at least to some degree, standarized, so it may be supposed that the effects of this were in all animals similar. It is not possible at present to exclude that excitability of animals is changing throughout the year. It is not, however, possible also to measure a degree of distortion, due to this factor. It should be not, it seems anyhow, overestimated, and may be ignored.

The number of pregnant females, which have been examined, was small. No decrease in $H b$ and $R B C$ values were noted in these animals, when compared with non-pregnant females caught at the same time.

It appears thus, that observed fluctuations in blood values depend not on age, sex, breeding, circadian behaviour or distortion due to nervous stress. These fluctuations seem to be correlated, on the other hand, with environmental seasonal changes directly, or indirectly through humoral factors.

The dependence of erythropoiesis on the dietetary factors has been well established. 
The role of protein seems to be especially great ( $\mathrm{B} \in \mathrm{th}$ a $\mathrm{r} d, 1958$; $\mathrm{Hahn}$ \& Whipple, 1939; Mille r et al., 1947). Many vitamins e.g. riboflavin, pyrodoxin, niacin, folic acid, thiamin, cobalamin (see $\mathrm{Sch}$ a $\mathrm{lm}, 1961)$ influenced this process. On the other hand, some constituents of diet may have detrimental influence on the erythropoiesis. The well known example of the last case is bracken fern poisonining in cattle (S i p p e 1, 1952).

The interrelationship between mechanism of erythropoiesis and humoral factors is more complicated. It is known, neverless, that after removal of thymus $R B C$ is increased, without any change in $H b$ concentration. Similar effect was observed after splenoctomy (R i d d l e \& B r a u c h e r, 1934). Thyroid, pituitary gland and adrenal glands deficiency affects also haemopoiesis (e.g. D a w s o n, 1956; S c h a l m, 1961).

The evaluation of dietetary factor is difficult. The availability of the food during the year cycle in forests of southern Poland has been examined by Grodziński (1961), Górecki \& Gębczyńska (1962) (see Fig. 7). This picture for the Białowieża National Park (North-eastern part of the country) should be modified, which is illustrated by B o r o ws k i \& D e hnel's (1952) data on number of insects there.

Some informations on seasonal changes of diet of common shrew, living in Białowieża forest, have been reported by $\mathrm{K}$ i s i e l e w s k a (1963). Her researches, based on helmintological findings, are, however, restricted to some snails and arthropoda diet components. They point to variability of shrew's food during the year cycle, but give no informations on the actual composition of the food in particular seasons.

In this connection the study of intestinal microflora may be used as an additional source of information.

The striking seasonal quantitative and qualitative changes of microflora of the intestine in $S$. araneus and $C$. glareolus have been described elsewhere (Kunicki-Goldfinger \& Kunicka-Goldfing e r, 1962).

Comparison of the data collected in Fig. 7 seems to suggest that the observed changes in haematological values, especially of haemoglobin concentration, are correlated with changes of diet. It may be presumed, that the change in haemoglobin concentration is the first to appear when diet is changed.

The influence of endocrine glands should not be underestimated (see Fig. 7, for changes in thymus, thyroid and testes - B a za n, 1952; Dzi erżykray - Rog a lska, 1952; Wolska, 1952), although the interrelationships between these and dietetary factors is undoubtly highly complicated. 
Fig. 7. Comparison of fluctuations of haematological values and seasonal variations of other morphological indices in $S$. araneus and C. glareolus.

$\mathrm{A}$ - acc. to Bielak \& Puc e k, 1960; B - acc. to $\mathrm{B}$ a z a n, 1952; C and D acc. to Wols k a, 1952; $\mathrm{E}$ - acc. to $\mathrm{Kunicki-}$ Goldfinger \& Kunicka - Goldfinger, 1962; $\mathrm{F}$ - acc. to Kow a ls ka Dy r c z, 1962, modified; G - acc. to Grodziński, 1961, modified; $\mathrm{H}-$ this report.

*) Activity of thyroid, as evaluated on the basis of histological data.

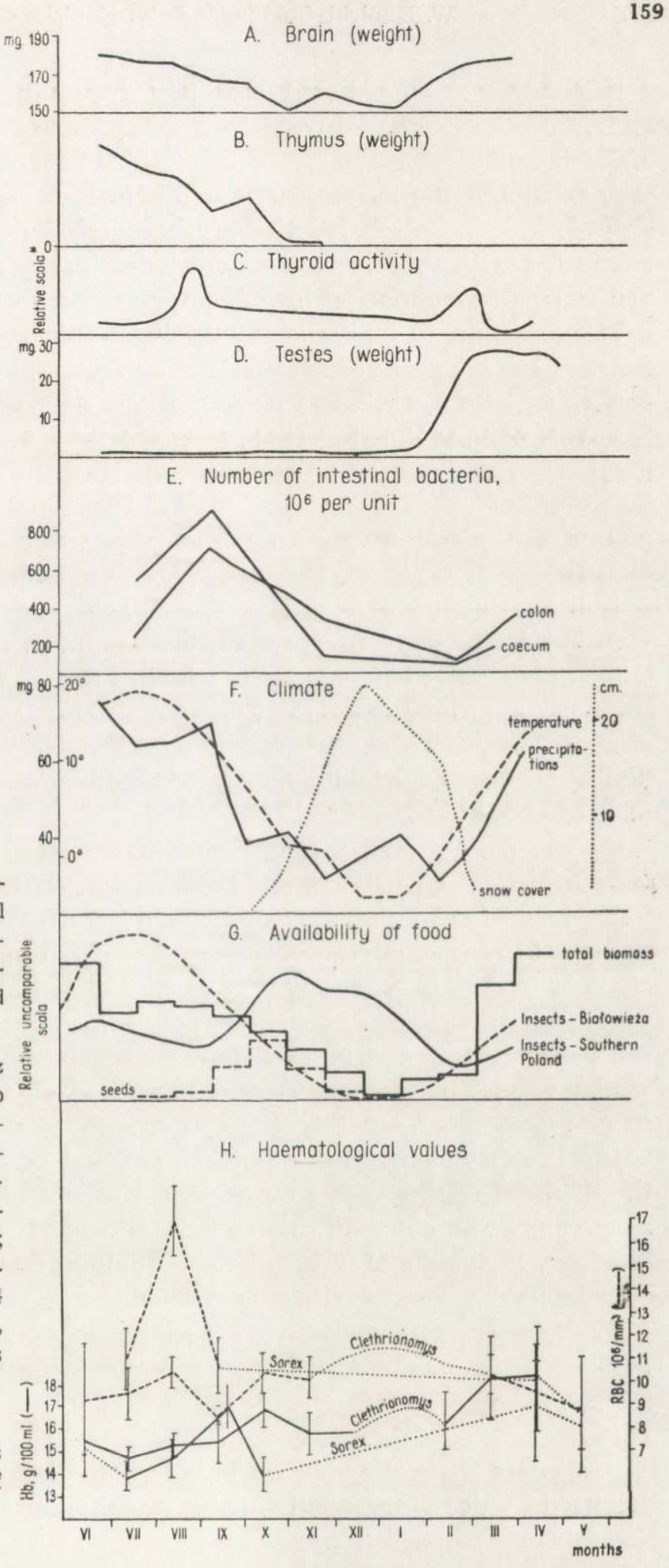


It should be remembered also that in small mammals the relative anoxia due to decreased partial oxygen pressure, especially in subnivean environment during winter period (Coulianos \& Johnels, 1962), may influence the haemopoiesis through the haemopoietin production in kidney. The increased level of erythrocyte count during winter may be connected with this mechanism and with higher metabolism rate, observed in small mammals at lower temperatures.

The exceedingly high and fluctuating erythrocyte counts in $S$. araneus can be caused by similar environmental factors, by very high metabolism rate (P e a r s o n, 1947) in this animal and its great activity.

In this connection, the study, reported by $\mathrm{N} \mathrm{e}$ w s o n (1962), should be mentioned. She excluded age, breeding, weather and ectoparasites, as possible factors affecting the pattern of seasonal fluctuations of haemoglobin concentration values in C. glareolus. She suggested, that the rate of turnover of erythrocytes is increased in summer, but no satisfactory reason for this has been offered.

Of special interest for present discussion, is, reported by $\mathrm{New}$ s o $\mathrm{n}$ (1962), difference between haemoglobin concentration values in free living voles and the caged ones. The animals were kept in cages in the same climatic conditions as the free-living ones. The haemoglobin concentration was in the caged animals, neverless, invariably distincly lower than in field-conditions.

S e a lander (1962) found good correlation between haemoglobin concentration and haematocrit values and mean maximum microhabitat temperature. On this basis, S e a l a n d e r has suggested, that seasonal changes in haemoglobin concentration of small mammals reflect seasonal changes in metabolism rate. It is worth yet to be noticed, that S e a l a nde $r$ found in caged animals distincly higher mean values of haemoglobin concentration and much narrower separation between summer and winter values, than among free living. According to him, seasonal changes in microhabitat temperature were more pronounced in cages, than in natural environment of the animals. It could be then expected, that also the differencies between summer and winter haemoglobin values should be greater. The chief difference between caged and free living animals has been in their diet. This factor, although mentioned, is dismissed by $\mathrm{S}$ e a l a nd e r from further discussion.

The effect of temperature, especially in connection with metabolic activity of small mammals, is not to be neglected. Metabolic activity affects, however, rather the erythrocyte count, than haemoglobin concentration.

It appears that following working hypothesis may be, at least pertially, justified by described results, being at the same time not inconsistent 
with data of $\mathrm{N} \mathrm{e}$ w S o n (1962) and S e a l a n d er (1962): in wild animals, living in their natural environment, the haemoglobin concentration mirrors the changes of diet; the erythrocyte count is, on the other hand, influenced to a great extent by the rate of metabolism, the activity of the animal and the partial oxygen pressure in its environment.

Fluctuations in mean corpuscular haemoglobin concentration are as marked as in erythrocytes count. The population heterogeneity in the respect of this value is caused by great differencies in MHC values between late summer minimum and late spring and early autumn maxima. It is evident that measurements of the haematological indices, without proper consideration for seasonal changes, my give misleading or false results.

\section{SUMMARY}

Haemoglobin concentration $(H b)$, erythrocyte count $(R B C)$, leucocyte count $(W C B)$ and mean corpuscular haemoglobin $(M C H)$ have been measured in $S$. araneus and C. glareolus during the year cycle.

In $S$. araneus at the beginning of the spring $R B C$ and $H b$ were low, increasing untill September, when they reached the highest values. During autumn $R B C$ level was low. The data for winter period were too scarse.

In C. glareolus there were two peaks in haemoglobin concentration (at spring and early autumn). The lowest values of $\mathrm{Hb}$ were found during late summer and in winter.

$R B C$ reached highest level at late summer and late autumn. The high level of $R B C$ was prolonged through the winter till early spring; minimal values were observed, correspondingly, et early autumn and very late spring.

No correlation was found between haematological values and age or sex of the animals.

The dietetary factors and endocrine glands activity were suggested as chief causes of changes in haemoglobin concentration. The metabolic activity and the partial oxygen pressure in the environment of the animals seem to be responsible for changes in the erythrocyte count. The exceedingly high and strongly fluctuating red blood cells count in S. araneus may be connected with these factors.

Acknowledgments: Special gratitude is due to late Professor Dr. August D e h n e l, who made this research possible, for His inspirations and helpful discussion. Thanks are also due to Mrs. Zofia K a r un os for technical assistance.

\section{REFERENCES}

1. B a z a n, I., 1952: Zmiany histomorfologiczne grasicy u Sorex araneus L. w cyklu życiowym. Ann. Univ. M. Curie-Skłodowska, C 7, 5: 253-304. Lublin.

2. B eth a r d, G. H., 1958: The effect of acute protein deprivation upon erythropoiesis in rats. Blood, 13: 216.

3. Bielak, T. \& Pucek, Z., 1960: Seasonal changes in the brain weight of the common shrew (Sorex araneus L.). Acta theriol., 3, 13: 297-300. Białowieża.

4. Borowski, S. \& Dehne 1, A., 1952: Materiały do biologii Soricidae. Ann. Univ. M. Curie-Skłodowska, C 7, 6: 305-448. Lublin.

5. Bula tova, N. N., 1962: Osobennosti krovi vysokogornych životnych. Tr. Inst, Morfol, Živ., 41: 11-46, 
6. Coulianos, C. C. \& Johnels, A. G., 1962: Note on the subnivean environment of small mammals. Ark. Zool., 15, 4: 363-370.

7. D a w s o n, J., 1956: Splenic hypertrophy in voles. Nature, 178, 4543: 1183-1184.

8. De hne 1, A., 1949: Badania nad rodzajem Sorex L. Ann. Univ. M. Curie-Skłodowska, C 4, 2: 17-97.

9. Drobkin, D. L. \& Fitz - H u g h, T., 1934: A comparison of the normal blood picture of rats of two different colonies reared upon different stock rations. Amer. J. Physiol., 108: 61-65.

10. Dudziński, M. L., Hesterman, E. R. \& Mykytowicz, R., 1962: Some haematological data from an experimental colony of rabbits, Oryctolagus cuniculus L. Austral. J. Zool., 10: 587-596.

11 D zierży kray - R og a lska, I., 1952: Zmiany histomorfologiczne tarczycy $S$. a. araneus $L$. Ann. Univ. M. Curie-Skłodowska, C 7, 4: 213-252.

12. Enzmann, E. V., 1934: The changes in haemoglobin concentration of blood of growing rats. Amer. J. Physiol., 108: 373.

13. Gorodeckij, V. K., 1962: Ekologo-fiziologičeskije osobennosti krovi severnogo olenia. Tr. Inst. Morfol. Ziv., 41: 47-90.

14. Górecki, A. \& Gębczyńska, Z., 1962: Food conditions for small rodents in a deciduous forest. Acta theriol., 6, 10: 275-295.

15. Grodzińs ki, W., 1961: Metabolism rate and bioenergetics of small rodents from the deciduous forest. Bull. Acad. Polon. Sci., Cl. II, 9, 12: 493-499.

16. $\mathrm{Hahn}, \mathrm{P} . \mathrm{F}$. \& Whipple, G. H., 1936: Haemoglobin production in anemia limited by low protein intake. J. Exp. Med., 69: 13.

17. Ha lberg, F., 1960: Temporal coordination of physiologic function. Cold Spring Harb. Symp. Quant. Biol., 25: 289-308.

18. H a n s e n, M. S., 1950: Studies on the hematology of the thoroughbred horse I., Amer. J. vet. Res., 11: 296.

19. Ka labukhov, N. I., 1933: Über die Verhältniss zwischen Grösse und Zahl der Erythrozyten, Hämoglobingehalt und Körpergrösse bei Citellus pygmaeus P a 11. Ztschr. Zellforsch. Mikrosk. Anat. 17: 1-24.

20. K is i e le w s k a, K., 1963: Food composition and reproduction of Sorex araneus L. in the light of parasitological research. Acta theriol., 7, 9: 127-153.

21. Kle in e $\mathrm{n}$ ber g, E. J., 1952: O primenenii vesovych indeksov $\mathrm{v}$ zoologii. DAN SSSR, 88, 3: 401-404.

22. Kno11, W., 1932: Untersuchungen über die Morphologie des Säugetierbluts. Folia haematol., 47: 201-219.

23. Koržujev, P. A. \& Koreckaja, T. I., 1962: Ekologo-fiziologičeskije osobennosti krovi zemleroek i krotov. Tr. Inst. Morfol. Živ. 41: 129-136.

24. Kowalska - Dy rcz, A., 1962: Seasonal variations in S. araneus L. in Poland. Acta theriol., 4, 14: 268-273.

25. Kunicki - Goldfinger, Wł. \& Kunicka - Goldfinger, Wł., 1962: Intestinal microflora of wild animals; Sorex araneus L. and Clethrionomys glareolus $\mathrm{S}$ c hre b. III. Seasonal changes. Acta microbiol. pol., 11, 1-2: 93-110.

26. Lucenko, S. D., 1941: acc. to G or odecki j, 1962.

27. Miller, L. L., Robscheit - Robbins, F. S. \& Whipple, G. H., 1947: Anaemia and hypoproteinemia. J. exp. Med., 85: 267.

28. Pearson, O. P., 1947: The rate of metabolism of some small mammals. Ecology, 28: 127-185.

29. N e w s on, J., 1962: Seasonal differencies in reticulocyte count, haemoglobin level and spleen weight in wild voles. Brit. J. Haematol., 8: 296-302. 
30. Pintor, P. P. \& Grasini, V., 1957: Individual and seasonal spontaneous variations of haematological values in normai male rabbits. Statistical survey. Acta haematol., 17: 122.

31. Riddle, O. \& Braucher, P. F., 1934: Hemoglobin and erythrocyte differencies according to sex and season in doves and pigeons. Amer. J. Physiol., 108: $554-566$.

32. S c h a $1 \mathrm{~m}$, O. W., 1961: Veterinary Hematology. Lea and Fiebiger, Philadelphia.

33. S e a lander, J. A., 1962: Seasonal changes in blood values of deer mice and other small mammals. Ecology, 43, 1: 107-119.

34 S i p pe 1, D. L., 1952: Bracken Fern poisoing. J. Amer. Vet. Med. Ass., 121: 9.

35. W introbe, M. M., j933: Variation in the size and hemoglobin content of erythrocytes in the blood of various vertebrates. Folia haematol., 51: 32.

36. W in trobe, M. M., 1952: Clinical Haematology. 3rd. ed., Lea-Fiebiger, Philadelphia,

Department of Microbiology,

Warsaw University,

Warsaw, Nowy Swiat 67.

\section{STRESZCZENIE}

Przebadano stężenie hemoglobiny, ilość czerwonych ciałek krwi, średnią zawartość hemoglobiny w krwince i ilość leukocytów u 51 osobników Clethrionomys glareolus (S chreber, 1780) i 27 osobników Sorex araneus L in na e us, 1758, złowionych w Białowieskim Parku Narodowym w ciągu całego cyklu rocznego.

U S. araneus ilość erytrocytów $(R B C)$ i zawartość hemoglobiny $(H b)$ były niskie w początkach wiosny, podnosząc się stale aż do września, gdy osiągnęły wartości maksymalne. Ilość krwinek czerwonych w jesieni ponownie spadła. Dane z okresu zimy były zbyt skąpe, by można było statystycznie ocenić istotność wahań (Tabela 1 , ryc. $1,2,3,5$ i 6 ).

U C. glareolus stwierdzono dwa maksima stężenia hemoglobiny (na wiosnę i wczesną jesienią). Najniższe zawartości $H b$ znaleziono późnym latem i zimą. Ilość erytrocytów osiągnęła maksima późnym latem i późną jesienią. Wysoki poziom erytrocytów przeciągnąl się przez zimę, aż do wczesnej wiosny. Minima obserwowano odpowiednio, wczesną jesienią i późną wiosną (Tabeia 1 , ryc. 1, 2, 3, 4 i 6 ).

Nie wykryto zależności między wskaźnikami hematologicznymi a wiekiem lub płcią zwierząt.

Jako główne przyczyny zmian stężenia hemoglobiny, proponuje się uznać czynniki żywieniowe i aktywność gruczołów dokrewnych. Aktywność metaboliczna i cząsteczkowe ciśnienie tlenu w środowisku są, jak się wydaje, odpowiedzialne za zmiany ilości erytrocytów. Wyjątkowo duże i silnie zmieniające się ilości erytrocytów u $S$. araneus mogą być ksztaltowane przez te czynniki (ryc. 7), 